\title{
Growth responses and accumulation of soluble sugars in Inga marginata Wild. (Fabaceae) subjected to flooding under contrasting light conditions
}

\author{
B. Bender ${ }^{a}$, E. S. Capellesso ${ }^{a}$, M. E. Lottici ${ }^{a}, J$. Sentkovski ${ }^{a}$, A. A. Mielniczki-Pereira ${ }^{b}$, \\ L. M. G. Rosac and T. L. Sausen ${ }^{a *}$ \\ a'Laboratório de Ecologia e Sistemática Vegetal, Departamento de Ciências Biológicas, Universidade Regional Integrada do \\ Alto Uruguai e das Missões - URI, Avenida Sete de Setembro, 1621, Centro, CEP 99700-000, Erechim, RS, Brazil

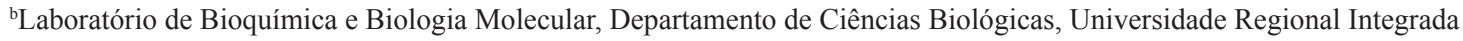 \\ do Alto Uruguai e das Missões - URI, Avenida Sete de Setembro, 1621, Centro, CEP 99700-000, Erechim, RS, Brazil \\ 'Laboratório de Ecofisiologia Vegetal, Departamento de Plantas Forrageiras e Agrometeorologia, Faculdade de Agronomia, \\ Universidade Federal do Rio Grande do Sul - UFRGS, Avenida Bento Gonçalves, 7712, Agronomia, \\ CEP 91540-000, Porto Alegre, RS, Brazil \\ *e-mail: tasausen@uricer.edu.br
}

Received: July 29, 2015 - Accepted: February 1, 2016 - Distributed: May 31, 2017

(With 1 figure)

\begin{abstract}
Flood events in riparian forests of southern Brazil, can be characterized as unpredictable and of low magnitude with an average duration of less than 15 days. Inga marginata is an evergreen tree which grows in Southeast South America on a wide range of environments, including riparian forests. In this paper, the interactive effects of the light environment and soil flooding on morphological parameters of I. marginata were examined. Seedlings were acclimated in two contrasting light conditions: sun or shade for 30 days. Sun and shade plants were subjected to soil flooding for two periods; five or 15 days. After 5 days, the interaction between flooding and light did not affect growth, chlorophyll content and dry mass or the root-shoot ratio. After 15 days, flooded plants from the sunny treatment had a lower shoot dry mass compared to control sun plants and flooded plants from the shaded treatment. Moreover, the higher dry mass observed for shade plants compared to sun plants, following flooding, can also be directly associated with a higher content of soluble sugars. Shade plants of I. marginata showed a greater acclimation to soil waterlogging. This acclimation appears to be associated with a larger accumulation of soluble sugars compared to non-flooded plants. The responses observed on the shade plants appear to be decisive to indicate the use of I. marginata in degraded areas.
\end{abstract}

Keywords: waterlogging, acclimation, plant dry mass, reforestation, riparian forests.

\section{Respostas de crescimento e acúmulo de açúcares solúveis em Inga marginata Willd. (Fabaceae) submetida ao alagamento e sob condições contrastantes de luminosidade}

\begin{abstract}
Resumo
As inundações em florestas ripárias do Sul do Brasil, podem ser caracterizadas como imprevisíveis e de baixa magnitude com uma duração média de menos de 15 dias. Inga marginata é uma árvore que cresce no sudeste da América do Sul em uma grande variedade de ambientes, incluindo matas ciliares. Neste trabalho, os efeitos combinados da luminosidade e do e alagamento do solo nos parâmetros morfológicos de I. marginata foram examinados. As plântulas foram aclimatadas em duas condições contrastantes de luminosidade: sol e sombra por 30 dias. Plantas de sol e sombra foram submetidas ao alagamento do solo por dois períodos; cinco ou 15 dias. Após 5 dias, a interação entre a inundação e luminosidade não afetou o crescimento, teor de clorofila e massa seca e a razão raiz-parte aérea. Após 15 dias, plantas de sol sob inundação apresentaram menor massa seca na parte aérea em relação as plantas controle de sol e as plantas alagadas de sombra. Além disso, a maior massa seca observada nas plantas de sombra em comparação com plantas de sol, sob inundação, pode ser diretamente associado com um maior teor de açúcares solúveis. Plantas de sombra de I. marginata mostraram uma maior aclimatação ao encharcamento do solo. Esta aclimatação parece estar associada com um maior acúmulo de açúcares solúveis em comparação com as plantas não-inundadas. As respostas observadas nas plantas de sombra parecem ser determinantes para a indicação do uso de I. marginata em áreas degradadas.
\end{abstract}

Palavras-chave: alagamento, aclimatação, massa seca da planta, reflorestamento, matas ciliares. 


\section{Introduction}

Riparian forests are formations adjacent to watercourses, with environments marked by exposure to frequent flooding (Naiman et al., 1998). Biological communities of riparian areas often are amongst the most productive and diverse in the world (Nilsson and Svedmark, 2002; Budke et al., 2008). In Brazil, the plains of the Amazon basin and the alluvial plain of the Pantanal are classic examples of large flood areas, showing seasonal rhythms of flooding, with alternating periods of flood and drought (Gonçalves et al., 2011). However, in the riparian forests of the Alto Uruguay region, in southern Brazil, the flood events can be characterized as unpredictable and of low magnitude, showing a reduced water column height, and with an average duration of less than 15 days, and can occur several times throughout the hydrological year (Budke et al., 2010).

In a study along the river Botucaraí riparian forest, Budke et al. $(2007,2008)$ found that the frequency of floods is an extremely efficient variable to predict species occurrence. Thus, the occurrence of a species might be determined by their tolerance to this disturbance (Budke et al., 2010). Although flood has a significant impact on the growth of some tree species, it is not the only parameter that determines their growth rate and establishment in riparian forests (Maurenza et al., 2012). Giehl and Jarenkow (2008) observed that floods, in riverine forests of Rio Grande do Sul, cause selectivity and usually result in the predominance of pioneering species in areas with frequent floods.

Flood events generate different impacts on trees, with some species dying rapidly during the waterlogging of the soil, whereas others are able to adapt and survive in such conditions (Silva et al., 2010). These differential responses occur due to the tolerance to oxygen deficiency on the waterlogged soil and involve some adaptive mechanisms in the roots, such as: i) the ability to oxidize the rhizosphere through the transfer of $\mathrm{O}_{2}$ from the shoot to the roots (Bartlett and James, 1993); ii) the formation of aerenchyma and adventitious roots on the stem that facilitate the rapid diffusion of $\mathrm{O}_{2}$ from the shoot to the roots; iii) an increased anaerobic respiration in roots and iv) the ability to regenerate new roots (Levitt, 1980; Koslowski, 2002).

Other adaptations to flooded environments involve a reduction in the rate of respiration, accompanied by the accumulation of soluble sugars (Qin et al., 2013), and compensatory changes in metabolism associated with differential allocation of biomass (Maurenza et al., 2009). In the natural environment, plants face the combination of a number of factors that can be constraints to their growth or determine their occurrence. Thus, the responses of species in contrasting light intensities and flood, which are determining factors in riparian forests, can be decisive in understanding the distribution patterns of tree species in these environments.
Inga marginata Willd. (Fabaceae) is an evergreen tree found in Southeast South America with a high ecological importance due to an abundant fruit production. Due to the rapid growth and high annual production of seeds, the species has been recommended for the reforestation of degraded areas, mainly in riparian forests (Budke et al., 2010). However, ecophysiological studies as a basis for their efficient use in forest recovery programs and its occurrence in areas subject to flooding are still scarce. Therefore, the aim of this study was to investigate the influence of a combination of two light levels and flooding on morphophysiological parameters of Inga marginata.

\section{Material and Methods}

\subsection{Plant material}

Fruits of a population of Inga marginata Willd. (Fabaceae) were collected on the campus of the University Regional Integrada do Alto Uruguai e das Missões, Erechim, RS, Brazil, on January 2012. After processing the fruits, the seeds were cleaned and placed in plastic trays containing Ferric Aluminium and vermiculite (3:1 ratio) in the laboratory of Systematics and Ecology of URI-Erechim to germinate. The average temperature during the germination period was $17.6^{\circ} \mathrm{C}$ and the photosynthetic photon flux density (PPFD) was $100 \mu \mathrm{mol} \mathrm{m} \mathrm{m}^{-2} \mathrm{~s}^{-1}$. After germination, and when the seedlings were about $3 \mathrm{~cm}$ high, the plants were transferred to plastic tubes with a volume of $100 \mathrm{~cm}^{3}$ with Ferric Aluminium and vermiculite substrate. The seedlings were then transferred to greenhouse conditions at a temperature and relative air humidity that accompanied the daily oscillations in the atmosphere, where they received irrigation for $10 \mathrm{~min}$ three times per day. These conditions were used for acclimation and initial growth. The average temperature during the experimental period was $18.9^{\circ} \mathrm{C}$ and relative humidity $71.9 \%$. Seedlings about three months old, with a mean height of $7.1 \mathrm{~cm} \pm 1.6 \mathrm{~cm}$, were used for this experiment

\subsection{Flooding and contrasting light conditions}

After the initial growth in the greenhouse, seedlings were acclimated for 30 days in two contrasting light environments: sun and shade, characterized as time zero. Shading was simulated on the greenhouse by using two layers of nylon mesh. The photosynthetic photon flux density (PPFD) for the sun plants was $556 \mu \mathrm{mol} \mathrm{m}^{-2} \mathrm{~s}^{-1}$ and shade plants $94.2 \mu \mathrm{mol} \mathrm{m} \mathrm{m}^{-2} \mathrm{~s}^{-1}$. After 30 days of growth in the sun and shade conditions, measurements to describe the morphological and physiological characteristics at time zero were conducted. The parameters evaluated were: shoot height, leaf number, leaf area, chlorophyll content with ClorofiLOG CFL 1030 (Falker, Brazil), shoot and root dry mass, the biomass allocation ratio and shoot and root soluble sugar content. For the evaluation of shoot and root dry mass, individual samples were dried in an oven at $60{ }^{\circ} \mathrm{C}$ for $48 \mathrm{~h}$, and were subsequently weighed on a precision analytical balance. 
Following the period of acclimation in contrasting light intensities, sun and shade plants were exposed to the following treatments: control plants, irrigated daily without water saturation of the soil (C) and partial flooding of the soil (PF). Plants were kept on the two water regimes for two periods of either five or 15 days. The parameters evaluated were: shoot height, leaf number, chlorophyll content with the aid of ClorofiLOG CFL 1030 (Falker, Brazil), shoot and root dry mass, the biomass allocation ratio and shoot and root soluble sugar content. For the evaluation of shoot and root dry mass, individual samples were dried in an oven at $60{ }^{\circ} \mathrm{C}$ for $48 \mathrm{~h}$, and were subsequently weighed on a precision analytical balance.

\subsection{Total soluble sugar content}

The extraction and quantification of soluble sugars was performed according to Dubois et al. (1956), with minor modifications. Samples with about $10 \mathrm{mg}$ of dry weight, obtained after homogenization in liquid nitrogen and drying in an oven at $40^{\circ} \mathrm{C}$, were extracted with $1 \mathrm{~mL}$ $80 \%$ ethanol and incubated in a water bath at $75{ }^{\circ} \mathrm{C}$ for $15 \mathrm{~min}$. The extracts were centrifuged at $12,000 \mathrm{rpm}$ for $15 \mathrm{~min}$ and the supernatant was recovered. The sediment was re-extracted with $500 \mu \mathrm{L} 80 \%$ ethanol and mixed with first extraction product. For quantification, $250 \mu \mathrm{L}$ of samples were mixed with $250 \mu \mathrm{L} 80 \%$ ethanol, $2.5 \mathrm{~mL}$ concentrated sulfuric acid and $0.5 \mathrm{~mL} 5 \%$ phenol. After agitation, the solutions were kept for $20 \mathrm{~min}$ at room temperature. The absorbance at $490 \mathrm{~nm}$ was measured in a spectrophotometer. A standard curve was established with D-glucose.

\subsection{Statistical analysis}

The experiment was conducted in a completely randomized $2 \times 2$ factorial design, with two light treatments (sun or shade) and two water status (flooded or non-flooded plants), resulting in a total of 100 plants. Before starting the flood treatments, a one-way ANOVA was used to analyze the light effects on the growth parameters and soluble sugar content. After the two flood periods, the growth variables and the soluble sugar content were analyzed by two-way ANOVA. When significant interactions were observed between treatments of light intensities and flooding, the means were analyzed by a t-test. All analyses were performed in Sigmaplot 11.0.

\section{Results and Discussion}

The classification of a species in different functional groups with respect to their light requirement and acclimation responses to the light environment, help define two distinct groups: species that are considered pioneers or sun species and sun-intolerant species or shade species (Valladares and Niinemets, 2008). The responses to variations in irradiance can occur at the leaf level and involve acclimation of the photosynthetic apparatus (Nobel, 1976; Givnish, 1988) or at the level of entire plant involving changes in growth pattern or biomass allocation (Chazdon and Smith, 1996). The ability of a given species to acclimate to sun or shade conditions can be demonstrated by an assessment of the initial growth under different light conditions, primarily through the analysis of the cost-benefits associated with the observed responses (Givnish, 1988).

During the initial growth (time zero), it was observed that Inga marginata seedlings grown under shade conditions had larger leaf area, shoot height and root length, accompanied by a higher shoot dry mass compared to roots (smaller root:shoot ratio) and a higher chlorophyll content index compared to sun plants (Table 1). The comparison between sun and shade plants showed no differences in leaf number, shoot, root, total dry mass and soluble sugar content. Our results, therefore, show similar trends to those of Gonçalves et al. (2005), Valladares and Niinemets (2008), Mielke and Schaffer (2010), all of whom observed the largest investment in growth, especially an increase in leaf area and photosynthetic pigments, in plants with similar ecological behavior including those acclimated to shade.

To understand the process of succession and natural regeneration in riparian forests, it is necessary to understand the existing light regimes within the forest, the adaptation of different species to these regimes, the processes related to the temporal succession of these species (Bazzaz and Carlson, 1982) and their response to flooding periods with different frequencies over time (Budke et al., 2010). Plants of Inga marginata that were acclimatized to contrasting light intensities did not show mortality when subjected to five

Table 1. Growth parameters and biomass accumulation in Inga marginata plants during acclimation to contrasting light intensities (time zero).

\begin{tabular}{lccc}
\hline \multicolumn{1}{c}{ Parameters } & Sun & Shade & $\boldsymbol{p}$ \\
\hline Height $(\mathrm{cm})$ & $6.31 \pm 1.21$ & $7.87 \pm 1.50$ & $0.02^{*}$ \\
Leaf number & $3.80 \pm 1.75$ & $3.90 \pm 0.56$ & 0.438 \\
Root length $(\mathrm{cm})$ & $4.51 \pm 1.13$ & $5.46 \pm 0.83$ & $0.048^{*}$ \\
Total Chlorophyll Index & $50.32 \pm 16.76$ & $66.73 \pm 8.34$ & $0.038^{*}$ \\
Shoot dry mass $(\mathrm{g})$ & $0.20 \pm 0.11$ & $0.28 \pm 0.07$ & 0.062 \\
Root dry mass $(\mathrm{g})$ & $0.12 \pm 0.08$ & $0.12 \pm 0.03$ & 0.992 \\
Total dry mass $(\mathrm{g})$ & $0.32 \pm 0.19$ & $0.40 \pm 0.09$ & 0.237 \\
R:S ratio & $0.59 \pm 0.15$ & $0.42 \pm 0.11$ & $0.015^{*}$ \\
Leaf Area $\left(\mathrm{cm}^{2}\right)$ & $900.70 \pm 384.50$ & $1631.80 \pm 595.90$ & $0.014^{*}$ \\
\hline
\end{tabular}

Values are means $\pm \mathrm{SD}(\mathrm{n}=10) .{ }^{*}$ Indicate difference between sun $v s$. shade plants within each parameter. 
or 15 days of partial flooding, which demonstrates that the species tolerates well soil waterlogging at different periods.

Sun and shade plants of Inga marginata showed different responses to flooding after periods of five or 15 days. After five days there was no effect of the interaction between flooding and light level on shoot height, leaf number, chlorophyll content, shoot, root and total dry mass, or the root:shoot ratio (Table 2). However, five days of flooding showed interaction between light levels and flood on root development. Greater root length in plants subjected to flooding and shade acclimated compared to that of the sun plants exposed to flooding was observed (Table 2). Shoot dry mass and plant total dry mass were affected only by light treatment. However, shade plants showed a higher chlorophyll content ( $p=0.015$ ) when exposed to flooded soil (Table 2).

After 15 days of flooding, the effects of light and flood treatments were more pronounced among control plants, which was demonstrated by the higher shoot height and chlorophyll content observed in sun control plants over shade control plants (Table 3 ). The light intensity had an effect on leaf number irrespective of flooding, with sun plants showing an increase in the number of leaves when compared to shade plants ( $p=0.004)$. The parameters of root length, root and total dry mass and the root:shoot ratio showed no differences between the treatments.

An increase in root length was observed in shade plants in response to flooding for five days. Flooding, however, had no marked effect on this plant response. After 15 days of flooding sun plants tended to show higher values for height and chlorophyll content. The effects of flooding, although not statistically significant, show a tendency of increasing these responses under shade (Table 3).

Sun plants on the control treatment (C) showed greater growth when compared to sun plants under flood. This indicates that flooding may be more severe under high-light environments. However, shade plants subjected to flooding for two weeks showed an acclimation response, which was demonstrated by no differences in almost all parameters between the control group and flooded plants.

The ability of some species to survive soil waterlogging is associated with mechanisms for hypoxic stress tolerance and the ability of roots to oxygenate the rhizosphere through the transfer of oxygen from shoots to roots (Bartlett and James,

Table 2. Growth parameters, biomass accumulation in sun and shade Inga marginata plants under control conditions (C) and subjected to partial flooding (PF) for five days.

\begin{tabular}{|c|c|c|c|c|c|}
\hline \multirow{2}{*}{ Parameters } & \multicolumn{2}{|c|}{ Sun } & \multicolumn{2}{|c|}{ Shade } & \multirow[b]{2}{*}{$p$} \\
\hline & $\mathbf{C}$ & PF & $\mathbf{C}$ & PF & \\
\hline Height (cm) & $7.20 \pm 1.37 \mathrm{Aa}$ & $6.66 \pm 1.63 \mathrm{Aa}$ & $8.00 \pm 1.67 \mathrm{Aa}$ & $7.38 \pm 1.27 \mathrm{Aa}$ & 0.92 \\
\hline Leaf number & $3.60 \pm 0.54^{\mathrm{Aa}}$ & $4.20 \pm 1.03^{\mathrm{Aa}}$ & $3.80 \pm 0.83^{\mathrm{Aa}}$ & $4.30 \pm 0.82^{\mathrm{Aa}}$ & 0.88 \\
\hline Root length (cm) & $5.88 \pm 1.46^{\mathrm{Bb}}$ & $5.46 \pm 0.85^{\mathrm{Bb}}$ & $5.40 \pm 0.74^{\mathrm{Bb}}$ & $6.63 \pm 0.81$ Аа & 0.03 \\
\hline Total Chlorophyll Index & $52.29 \pm 9.02^{\mathrm{Bb}}$ & $50.66 \pm 9.96^{\mathrm{Bb}}$ & $57.68 \pm 9.02^{\mathrm{Bb}}$ & $63.16 \pm 7.46^{\mathrm{Aa}}$ & $0.32 *$ \\
\hline Shoot dry mass (g) & $0.21 \pm 0.03^{\mathrm{Bb}}$ & $0.19 \pm 0.08^{\mathrm{Bb}}$ & $0.26 \pm 0.05^{\mathrm{Aa}}$ & $0.27 \pm 0.03^{\mathrm{Aa}}$ & $0.63 *$ \\
\hline Root dry mass (g) & $0.12 \pm 0.01^{\mathrm{Aa}}$ & $0.11 \pm 0.03^{\mathrm{Aa}}$ & $0.14 \pm 0.03 \mathrm{Aa}$ & $0.12 \pm 0.10^{\mathrm{Aa}}$ & 0.94 \\
\hline Total dry mass (g) & $0.33 \pm 0.04^{\mathrm{Bb}}$ & $0.33 \pm 0.11^{\mathrm{Bb}}$ & $0.40 \pm 0.08^{\mathrm{Aa}}$ & $0.41 \pm 0.07^{\mathrm{Aa}}$ & $0.69 *$ \\
\hline $\mathrm{R}: \mathrm{S}$ ratio & $0.58 \pm 0.19^{\text {Аа }}$ & $0.57 \pm 0.18^{\mathrm{Aa}}$ & $0.52 \pm 0.06^{\mathrm{Aa}}$ & $0.46 \pm 0.10^{\mathrm{Aa}}$ & 0.62 \\
\hline
\end{tabular}

Values are means $\pm \mathrm{SD}(\mathrm{n}=10) . P$ value refers to the interaction between light and water treatments. Different letters indicate significant differences within each parameter evaluated. *Indicates difference alone (without interaction) arising or light or water status factor. Uppercase letters (compare the parameters within each light treatment) and lowercase (compare the parameters within each water status) equal, do not differ by Tukey test a $5 \%$ probability.

Table 3. Growth parameters and biomass accumulation in sun and shade Inga marginata plants under control conditions (C) or subjected to partial flooding (PF) for 15 days.

\begin{tabular}{|c|c|c|c|c|c|}
\hline \multirow{2}{*}{ Parameters } & \multicolumn{2}{|c|}{ Sun } & \multicolumn{2}{|c|}{ Shade } & \multirow{2}{*}{$p$} \\
\hline & $\mathbf{C}$ & PF & $\mathbf{C}$ & PF & \\
\hline Height (cm) & $8.44 \pm 1.29^{\mathrm{Aa}}$ & $6.66 \pm 1.78^{\mathrm{Bb}}$ & $6.22 \pm 1.23^{\mathrm{Bb}}$ & $6.86 \pm 1.04^{\mathrm{Bb}}$ & 0.035 \\
\hline Leaf number & $4.00 \pm 0.70^{\mathrm{Aa}}$ & $4.20 \pm 1.13 \mathrm{Aa}$ & $2.60 \pm 0.54 \mathrm{Bb}$ & $3.60 \pm 0.51^{\mathrm{Bb}}$ & $0.215^{*}$ \\
\hline Root length (cm) & $6.22 \pm 0.62$ Аa & $5.64 \pm 1.23^{\text {Аа }}$ & $5.36 \pm 0.96^{\mathrm{Aa}}$ & $5.61 \pm 0.95 \mathrm{Aa}$ & 0.304 \\
\hline Total Chlorophyll Index & $63.92 \pm 9.19^{\text {Аа }}$ & $53.85 \pm 12.56^{\mathrm{Bb}}$ & $45.34 \pm 7.03^{\mathrm{Bb}}$ & $58.43 \pm 18.02^{\mathrm{Bb}}$ & 0.038 \\
\hline Shoot dry mass (g) & $0.26 \pm 0.08^{\mathrm{Aa}}$ & $0.22 \pm 0.05^{\mathrm{Bb}}$ & $0.22 \pm 0.04 \mathrm{Bb}$ & $0.27 \pm 0.05^{\mathrm{Ba}}$ & 0.047 \\
\hline Root dry mass (g) & $0.15 \pm 0.04^{\mathrm{Aa}}$ & $0.11 \pm 0.05 \mathrm{Aa}$ & $0.13 \pm 0.02$ Аа & $0.13 \pm 0.02^{\mathrm{Aa}}$ & 0.143 \\
\hline Total dry mass (g) & $0.42 \pm 0.12^{\mathrm{Aa}}$ & $0.33 \pm 0.09$ Аа & $0.35 \pm 0.06^{\mathrm{Aa}}$ & $0.41 \pm 0.08^{\mathrm{Aa}}$ & 0.058 \\
\hline $\mathrm{R}: \mathrm{S}$ ratio & $0.58 \pm 0.07 \mathrm{Aa}$ & $0.49 \pm 0.16^{\mathrm{Aa}}$ & $0.57 \pm 0.04^{\mathrm{Aa}}$ & $0.48 \pm 0.06^{\mathrm{Aa}}$ & 0.952 \\
\hline
\end{tabular}

Values are means $\pm \mathrm{SD}(\mathrm{n}=10) . P$ value refers to the interaction between light and water treatments. Different letters indicate significant differences within each parameter evaluated. *Indicates difference alone (without interaction) arising or light or water status factor. Uppercase letters (compare the parameters within each light treatment) and lowercase (compare the parameters within each water status) equal, do not differ by Tukey test a $5 \%$ probability. 
1993; Perata and Alpi, 1993), via biomass allocation and growth responses (Koslowski, 2002; Mielke and Schaffer, 2010). However, another important adaptation in flood conditions is the storage of nonstructural carbohydrates (soluble sugars and starch) in different regions of the plant (Vartapetian and Jackson, 1997; Kawano et al., 2009).

The flooding response in shade plants at five and 15 days might be associated with the temporal pattern of shoot and root accumulation of soluble sugars compared to that for plants at time zero $(p=0.05)$ (Figure $1 \mathrm{~A}$ and $1 \mathrm{~B})$. After five days of flooding, roots were longer and had a higher content of soluble sugars compared to the control group $(p=0.012)$ (Figure 1A and 1B). Moreover, the higher shoot and total dry mass observed for the shaded plants compared to the sun plants, under flooding, might also be directly associated with a higher soluble sugar content in shade plants compared to sun plants, which was similar at five and 15 days. The higher shoot dry mass in shaded plants was also observed by Ferreira et al. (2001) in an experiment with Piptadenia gonoacantha using different waterlogging conditions and light intensities.

According to Chazdon and Smith (1996), physiological plasticity and the ability to acclimate to different light
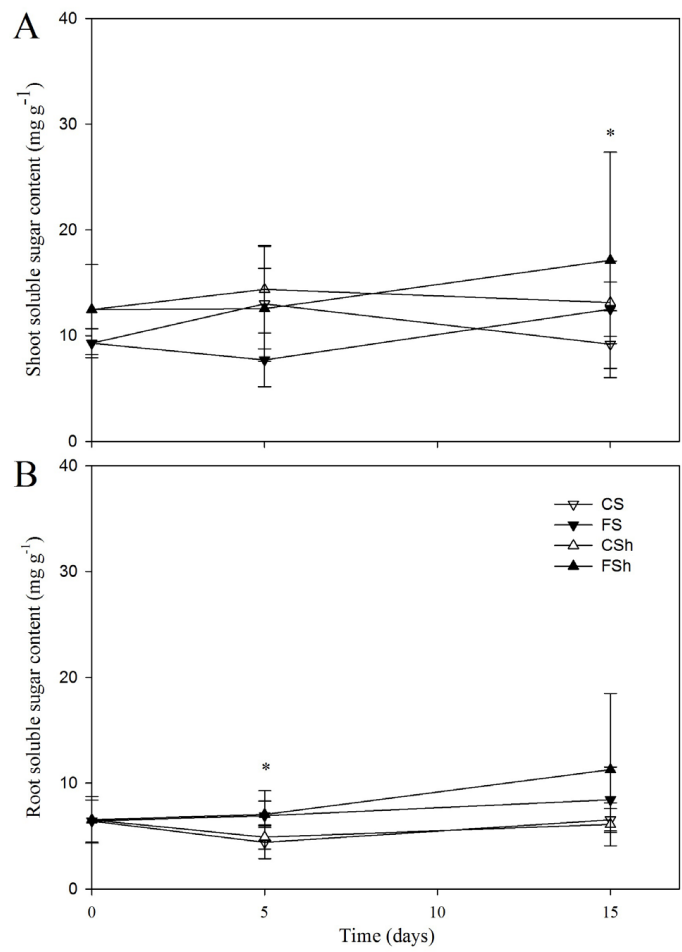

Figure 1. Time course of shoot (A) and root (B) soluble sugars content in sun and shade Inga marginata plants under control conditions and partial soil flooding. Control sun plants (CS), control shade plants (CSh), flooded sun plants (FS) and flooded shade plants (FSh). Values are mean \pm standard deviation $(\mathrm{n}=5)$. *Indicate difference between flooded vs. control plants. regimes are related to the successional group to which the species belongs. The plasticity describes the phenotypic response that is expressed by environmental conditions, whereas the flexibility (or acclimation) is regarded as the process by which plasticity is expressed. The results of this study indicated that the chlorophyll content was higher in shade plants and after flood for five days. The increase in chlorophyll content appears to reflect an acclimation to low light intensity, probably to downregulation photosynthesis process and thus tolerate the combined effect of floods and shading.

Valladares et al. (2000b) suggest that pioneer species in the succession process exhibit greater phenotypic plasticity and ability to adapt to environments with high light than secondary species (Valladares et al., 2002). The lowest phenotypic plasticity in secondary species can also be associated with a conservative strategy in resource use (Valladares et al., 2000a). Inga marginata is classified as an early successional species in the forest succession process, indicating that plants acclimated to sun and under unfavorable water conditions are often more sensitive to the effects of soil waterlogging compared to shade plants.

The results here indicate that Inga marginata can partially tolerate soil waterlogging and that the response to flooding differs with respect to the light environment. Flooding and contrasting light conditions influenced the development of I. marginata plants, as shade plants showed a greater acclimation to waterlogged environments. This acclimation appears to be associated, among other factors, with a greater accumulation of soluble sugars than control and sun plants.

Qin et al. (2013) argue that lower consumption and faster accumulation of soluble sugars are mechanisms associated with flooding tolerance. These data corroborate the results of the present study, where was observed that both plants grown in the shade and those grown in the light, when subjected to flooding, show an increase in soluble sugars in the root, indicating a general adaptation in response to water in the soil.

In sum, the results of this study indicate that despite its tolerance to short periods of partial flooding, caution is required in the use of Inga marginata for reforestation in riparian areas, which is often marked by a high light, since luminosity could be a negative factor in relation to the acclimation to flooded conditions for this species.

\section{Acknowledgements}

The authors thanks to the "Programa de Pós-Graduação em Ecologia" and to the Department of Biological Sciences of Universidade Regional Integrada do Alto Uruguai e das Missões - URI for financial support to our study. M.E. Lottici and J. Sentkvoski received grants program NETWORKS-URI and E. Capelesso received grants from the Coordination of Improvement of Higher Education Personnel (CAPES, Brazil). 


\section{References}

BARTLETT, R.J. and JAMES, B.R., 1993. Redox chemistry of soil. Advances in Agronomy, vol. 50, pp. 151-208. http://dx.doi. org/10.1016/S0065-2113(08)60834-2.

BAZZAZ, F.A. and CARLSON, R.W., 1982. Photosynthetic acclimation to variability in the light environment of early and late successional plants. Oecologia, vol. 54, no. 3, pp. 313-316. http://dx.doi.org/10.1007/BF00379999.

BUDKE, J.C., JARENKOW, J.A. and OLIVEIRA-FILHO, A.T., 2007. Relationships between tree component structure, topography and soils of a riverine forest, Rio Botucaraí, Southern Brazil. Plant Ecology, vol. 89, no. 2, pp. 187-200. http://dx.doi.org/10.1007/ s11258-006-9174-8.

BUDKE, J.C., JARENKOW, J.A. and OLIVEIRA-FILHO, A.T., 2008. Tree community features of two stands of riverine Forest under different flooding regimes in Southern Brazil. Flora, vol. 203, no. 2, pp. 162-174. http://dx.doi.org/10.1016/j.flora.2007.03.001.

BUDKE, J.C., JARENKOW, J.A. and OLIVEIRA-FILHO, A.T., 2010. Florestas ribeirinhas e inundações: de contínuos espaciais e gradientes temporais. In: J.E. SANTOS, E.M. ZANIN and L.E. MOSCHINI, eds. Faces da polissemia da paisagem: ecologia, planejamento e percepção. São Carlos: Rima, vol. 3, pp. 201-218.

CHAZDON, R.L. and SMITH, A.P., 1996. Tropical forest plant ecophysiology. New York: Chapman \& Hall.

DUBOIS, M., GILLES, K.A., HAMILTON, J.K., REBERS, P.A. and SMITH, F., 1956. Colorimetric method for determination of sugars and related substances. Analytical Chemistry, vol. 28, no. 3, pp. 350-356. http://dx.doi.org/10.1021/ac60111a017.

FERREIRA, J.N., RIBEIRO, J.F. and FONSECA, C.E.L., 2001. Crescimento inicial de Piptadenia gonoacantha (Leguminosae, Mimosoideae) sob inundação em diferentes níveis de luminosidade. Brazilian Journal of Botany, vol. 24, no. 4, pp. 561-566. http:// dx.doi.org/10.1590/S0100-84042001000500011.

GIEHL, E.L. and JARENKOW, J.A., 2008. Gradiente estrutural no componente arbóreo e relação com inundações em uma floresta ribeirinha, no Uruguai, sul do Brasil. Acta Botanica Brasílica, vol. 22 , no. 3, pp. 741-753. http://dx.doi.org/10.1590/S010233062008000300012

GIVNISH, T.J., 1988. Adaptation to sun and shade: a whole-plant perspective. Australian Journal of Plant Physiology, vol. 15, no. 2, pp. 63-92. http://dx.doi.org/10.1071/PP9880063.

GONÇALVES, H.C., MERCANTE, M.A. and SANTOS, E.T., 2011. Hydrological cycle. Brazilian Journal of Biology = Revista Brasileira de Biologia, vol. 71, no. 1, suppl. 1, pp. 241-253. PMid:21537597.

GONÇALVES, J.F.C., BARRETO, D.C.S., SANTOS-JUNIOR, U.M., FERNANDES, A.V., SAMPAIO, P.T.B. and BUCKERIDGE, M.S., 2005. Growth, photosynthesis and stress indicators in young rose wood plants (Aniba rosaeodora Ducke) under different light intensities. Brazilian Journal of Plant Physiology, vol. 17, no. 3, pp. 325-334. http://dx.doi.org/10.1590/S1677-04202005000300007.

KAWANO, N., ITO, O. and SAKAGAMI, J.I., 2009. Morphological and physiological responses of rice seedlings to complete submergence (flash flooding). Annals of Botany, vol. 103, no. 2, pp. 161-169. http://dx.doi.org/10.1093/aob/mcn171. PMid:18940854.

KOSLOWSKI, T.T., 2002. Physiological-ecological impacts of flooding on riparian forest ecosystems. Wetlands, vol. 22, no. 3, pp.
550-561. http://dx.doi.org/10.1672/0277-5212(2002)022[0550:PE IOFO]2.0.CO;2.

LEVITT, J., 1980. Responses of plants to environmental stress: water, radiation, salt and other stresses. New York: Academic Press.

MAURENZA, D., MARENCO, R.A. and PIEDADE, M.T.F., 2009. Efeito da inundação de longa duração sob o crescimento de Pouteria glomerata (Sapotaceae), uma arbórea da várzea da Amazônia Central. Acta Amazonica, vol. 39, no. 3, pp. 519-526. http://dx.doi.org/10.1590/S0044-59672009000300005.

MAURENZA, D., MARENCO, R.A., PAROLIN, P. and PIEDADE, M.T.F., 2012. Physiological responses to flooding and light in two tree species native to the Amazonian floodplains. Aquatic Botany, vol. 96, no. 1, pp. 7-13. http://dx.doi.org/10.1016/j. aquabot.2011.09.003.

MIELKE, M.S. and SCHAFFER, B., 2010. Photosynthetic and growth responses of Eugenia uniflora L. seedlings to soil flooding and light intensity. Environmental and Experimental Botany, vol. 68, no. 2, pp. 113-121. http://dx.doi.org/10.1016/j. envexpbot.2009.11.007.

NAIMAN, R.J., FETHERSTON, K.L., MCKAY, S.J. and CHEN, J., 1998. Riparian forests. In: R.J. NAINAN and R.E. BILBY, eds. River ecology and management: lessons from the Pacific Coastal Ecoregion. New York: Springer-Verlag, pp. 289-323. http://dx.doi.org/10.1007/978-1-4612-1652-0_12.

NILSSON, C. and SVEDMARK, M., 2002. Basic principles and ecological consequences of changing water regimes: riparian plant communities. Environmental Management, vol. 30, no. 4, pp. 468-480. http://dx.doi.org/10.1007/s00267-002-2735-2. PMid:12481914.

NOBEL, P.S., 1976. Photosynthetic rates of sun versus shade leaves of Hyptis emoryi Torr. Plant Physiology, vol. 58, no. 2, pp. 218-223. http://dx.doi.org/10.1104/pp.58.2.218. PMid:16659651.

PERATA, P. and ALPI, A., 1993. Plant responses to anaerobiosis. Plant Science, vol. 93, no. 1-2, pp. 1-17. http://dx.doi.org/10.1016/01689452(93)90029-Y

QIN, X., LI, F., CHEN, X. and XIE, Y., 2013. Growth responses and non-structural carbohydrates in three wetland macrophyte species following submergence and de-submergence. Acta Physiologiae Plantarum, vol. 35, no. 7, pp. 2069-2074. http:// dx.doi.org/10.1007/s11738-013-1241-x.

SILVA, A.C., HIGUCHI, P. and VAN DEN BERG, E., 2010. Effects of soil water table regime on tree community species richness and structure of alluvial forest fragments in Southeast Brazil. Brazilian Journal of Biology $=$ Revista Brasileira de Biologia, vol. 70, no. 3, pp. 465-471. http://dx.doi.org/10.1590/ S1519-69842010000300002. PMid:20730335.

VALLADARES, F. and NIINEMETS, U., 2008. Partial sunlight tolerance, a key plant feature of complex nature and consequences. Annual Review of Ecology Evolution and Systematics, vol. 39, no. 1, pp. 237-257. http://dx.doi.org/10.1146/annurev. ecolsys.39.110707.173506.

VALLADARES, F., CHICO, J.M., ARANDA, I., BALAGUER, L., DIZENGREMEL, P., MANRIQUE, E. and DREYER, E., 2002. Greater high light seedling tolerance of Quercus robur over Fagus sylvatica is linked to a greater physiological plasticity. Trees Structure and Function, vol. 16, pp. 395-403.

VALLADARES, F., MARTINEZ-FERRI, E., BALAGUER, L., PEREZ-CORONA, E. and MANRIQUE, E., 2000a. Low leaflevel response to light and nutrients in Mediterranean evergreen oaks: a conservative resource-use strategy? The New Phytologist, 
vol. 148, no. 1, pp. 79-91. http://dx.doi.org/10.1046/j.14698137.2000.00737.x.

VALLADARES, F., WRIGHT, S.J., LASSO, E., KITAJIMA, K. and PEARCY, R.W., 2000b. Plastic phenotypic response to light of 16 congeneric shrubs from a Panamanian rainforest. Ecology, vol. 81, no. 7, pp. 1925-1936. http://dx.doi.org/10.1890/00129658(2000)081[1925:PPRTLO]2.0.CO;2.

VARTAPETIAN, B.B. and JACKSON, M.B., 1997. Plant adaptations to anaerobic stress. Annals of Botany, vol. 79, suppl. 1, pp. 3-20. http://dx.doi.org/10.1093/oxfordjournals.aob.a010303. 